\title{
EDUCATION AND INDUSTRIAL JOB ACQUISITION IN BRAZIL: TOWARDS AN IMPROVED CAUSAL MODEL*
}

\author{
RAINER H. LEHMANN \\ Fachbereich Erziehungswissenschaft, Universität Hamburg \\ and \\ ROBERT E. VERHINE \\ Faculdade de Educacao, Universidade Federal da Bahia
}

\begin{abstract}
This paper offers a model of the job obtainment process experienced by factory workers, based on data from a sample of male applicants for skilled manual work in Bahia's Centro Industrial de Aratu. It provides information on the economic significance of alternative modes of education and, at the same time, illustrates the usefulness of path analysis in assessing the direct and indirect effects of potential determinants of employment. The results of the study reveal that informal, nonformal and formal education all exert some impact on job obtainment, although, in the case of each factor, the magnitude of the contribution is dependent upon the nature of measurement utilized. The outcomes are, in general, consistent with the hypothesis that employers prefer 'trainable' workers over those already trained.
\end{abstract}

\section{INTRODUCTION}

Brazil is presently facing an expansion of needs for education and vocational training and, at the same time, is finding it increasingly difficult to allocate funds and efforts properly to such purposes. Dwindling public resources make rational educational planning and policymaking ever more important, and these processes, in turn, require an understanding of the complex relationships between alternative modes of learning and the socio-economic outcomes of educational endeavours. In this context, it is meaningful to model the paths taken by individuals as they move through educational programs/institutions into working life. By so doing, it is possible to shed light on the economic significance of education (in all of its varieties) for workers and employers in Brazil.

Scholars involved in the field of education and development generally recognize the

* A slightly different version of this article has been published in Portuguese in Pesquisa e Planejamento Economico, 16 (3), 621-646, December, 1986. importance of considering not only particular institutions or programs but also the interaction between formal, nonformal and informal educational modes (LaBelle, 1976; King, 1980). It seems appropriate, therefore, to regard the whole domain of learning experiences as a source for economically relevant attributes and then determine the extent to which each mode (1) adds to an individual's chances of obtaining employment and (2) contributes to his or her opportunities for advancement. Although implicitly suggesting a method for dealing with both issues, the present article restricts its focus to the first of the two mentioned aspects. Using data derived from a small sample of male applicants for skilled manual industrial work interviewed at personnel offices of five modern factories in Bahia's Centro Industrial de Aratu, the paper seeks to illustrate the relative direct and indirect contributions of formal, nonformal and informal education to job obtainment in the modern industrial sector of the Brazilian Northeast. In so doing, it presents a refined version of a recursive causal model introduced in rudimentary form in an earlier publication (see Lehmann and Verhine, 1982). 


\section{THEORETIC.AL ISSUES}

Causal models in the social sciences presuppose the existence of a body of theoretical/ analytical knowledge which determines the structure of interrelationships between the variables involved (Blalock, 1971; Duncan, 1975). Thus, any inferences drawn are as dependent on the validity of the underlying theoretical framework as they are on the measurement of the concepts used. It is appropriate, therefore, to review the theoretical issues which contributed to the design of the present research.

(1) Two decades ago it was widely believed that national development and individual productivity, income and status could be promoted by heavy investment in formal schooling. This assumption was supported by correlations observed between educational attainments and various socio-economic output measures (Blau and Duncan, 1967; Carnoy, 1967; Castro, 1970; Harbinson and Myers, 1964). It was also sustained by the theory of human capital, a perspective based on neoclassical economic thinking which posits that education generates productive skills and abilities and thus yields a string of economic benefits (both private and social) over time (Schultz, 1961; Becker, 1964). By the early 1970s, however, a combination of rising schooling costs (Coombs, 1968), new data suggesting very limited in-school effects (Averch et al., 1972; Jcncks et al., ${ }^{-1972)}$ and the popularization of conflict-based reproduction theory (Bowles, 1971; Bourdieu and Passeron, 1970; Collins, 1971) had generated much pessimism on the part of scholars and policy makers toward the potential of formal schooling as an instrument of social betterment. As a result, a worldwide search for educational alternatives was set in motion and the terms 'nonformal education' and 'informal education' came into vogue (Brembeck and Thompson, 1973; Paulston, 1972). Today the relative impact (or lack thereof) of these alternative modes, like that associated with traditional schooling, is a subject of considerable debate (LaBelle, 1975, 1976; Verhine and Lehmann, 1980). Thus, there is clearly a need for integrating all three activities into occupational determination models, in a manner which considers both independent and complementary effects.

(2) In looking at nonformal education and, more specifically, vocational training, it is apparent that a distinction must be made between 'general' training which raises worker productivity in many firms alike and 'specific' training that adds to worker marginal output only or predominantly in the firm providing the learning experience (Becker, 1964). Works by Thurow (1975) in the United States and Castro and Mello e Souza (1974) in Brazil have added dimension to the general/specific training issue by distinguishing between learning appropriate for 'trainability' (general education) and learning which is itself training (specific education). These writings treating the general/specific question, however, are theoretical in nature; there is very little empirical evidence pertinent to the debate. Thus, in dealing with nonformal education in the context of data-informed structural equation models, it is essential to treat the two aspects (general and specific) as separate components in order to clarify the roles of each in the labor market.

(3) A third theoretical issue which has dominated much of the debate concerning education/economic system relationships concerns the question of why education might lead to occupational success. Blaug (1973) has summarized this controversy as one between 'economic', 'social' and 'psychological' explanations. Others have employed different category labels, including the authors of this present work (Verhine and Lehmann, 1980; Verhine, 1982), but all agree that distinctions must be drawn between those who trace educational effects to human capital formation, those who posit that its contribution rests in an ability to inculcate 'proper' personality and behaviorial traits, and those who believe that education's real value is derived from its socially mandated screening and credentialing function. It is imperative, therefore, that the potential validity of all or a portion of each of these perspectives be taken into account when specifying and interpreting models defining job obtainment processes.

(4) In the study of formal and nonformal educational modes, it should be recognized that these two processes are imbedded in informal learning configurations. The latter are extremely difficult to measure, although their impact probably exceeds the observed effects of systematically organized education. No more can be done here than to try to neutralize 
these confounding effects by controlling for such experience-related variables as residential background, age and accumulated time on the job.

(5) It has been argued that even in Brazil's modern economic sector the distribution of positions is influenced by personalism, a remnant, perhaps, of Brazil's once pervasive traditional, agrarian social structure (Leeds, 1964). If personalism indeed be a factor, the impact of educational efforts in the labor market is likely constrained by non-economic considerations. In this context, the fact that the job candidate is or is not recommended for the position by someone known to the employer (such as one of his workers) could have bearing on hiring outcomes. On the other hand, it is also possible that recommendations serve to identify the truly capable, especially if, as Buschmann (1977) suggests, recommenders seek to protect their own status by indicating only the most likely to succeed. In this sense, then, recommendations may complement training effects, providing an avenue of access for those who are best prepared. In any event, it is clearly important to incorporate a variable for recommendation in models designed to describe relationships between qualification profiles and job acquisition.

(6) Finally, it must not be overlooked that employment decisions may be influenced by technological and organizational characteristics of the enterprise. Firm size and complexity, for example, has been shown to be positively associated with the existence or absence of in-plant training facilities (Edfelt, 1975) and, in turn, in-plant training tends to be that which is most specific in nature (Becker, 1964). Thus, firm size should impinge on the degree to which the company prefers trained or trainable workers (larger firms should prefer the latter because they have their own training facilities) and, as a consequence, it probably interacts with the entire job obtainment process. Obviously, this factor, like the others outlined in the paragraphs above, must be incorporated into the analysis.

The need to address simultaneously the various aspects reviewed above suggests the use of a research strategy based on biographical data which considers, concomitantly, complex interrelationships between a set of direct and indirect occupational determinants. As mentioned earlier, the small size of the sample used here poses obvious limitations to the generalizability of actual findings. Therefore, much emphasis is given in the present paper to questions of methodology and data analysis techniques in the hope that similar studies with a greater number of observations will be able to adopt similar processing procedures and examine in greater depth the hypotheses and conclusions suggested herein.

\section{HYPOTHETICAL ANALYTICAL MODEL}

Since at this point one is dealing with a complex network of interlocking components, it is essential to specify a structure that determines the relationships between the constructs involved. Likewise, these assumed relationships must be understood as being dependent on the specific set of operationalizations employed. This, of course, has certain implications for the process of data collection. The strategy employed in this study involves collecting information on various aspects of educational participation and relating the particular combinations of aspects encountered with observed employment outcomes. The central objective of this study, then, is to determine the extent to which alternative components of educational experience (formal, nonformal and informal) contribute to the acquisition of employment in the modern industrial sector of the economy. Alternative educational involvements are assumed to have linearly additive, mutually independent effects, while context effects are controlled for by assigning them an additive-linear contribution of their own. This simple approach alone, however, is insufficient because it obviously runs counter to the argument made above concerning the need to investigate the relationships between learning modes. Thus, it is necessary to take these relationships conceptually and structurally into account, a process accomplished by incorporating into the model the sequential/temporal order in which different experiences are acquired.

Before relating the details of the causal structure developed for this study, it is appropriate to briefly review how the terms 'formal education', 'nonformal education' and 'informal education' as well as the notion of 'context effects' are defined in the analysis. 


\section{(1) Formal education}

Although it is customary in studies of the economic consequences of education to measure formal schooling (FE) in terms of time spent (or grade levels completed) within the official educational system, a somewhat different approach was chosen here. It was assumed that Brazilian employers, when hiring for skilled manual positions, are reluctant to hire not only those with less than a minimal amount of formal instruction (to guarantee trainability and 'proper' socialization) but also those with more than a maximum amount of traditional schooling. This hypothesis of a negative over-education effect is supported by findings reported by Berg (1970), Castro and Mello e Souza (1974) and Menezes (1987) that reveal that too much schooling may lead to job discontent and/or a tendency for the worker to abandon his employment in search of either a better position or further study. Menezes indicates, for example, based on data collected from employers in Salvador, that some firms prefer not to employ people with advanced levels of instruction 'por causa do seu grau de aspiracao, o que as levaria a utilizar a ocupacao como trampolim' (Menezes, 1987, p. 87). In line with this thinking, the dichotomous variable 'job obtainment' (hired/not hired) was crosstabulated with a variable measuring the number of successfully completed years of formal schooling. The results are shown in Table 1.

These outcomes show that those most likcly to be employed have between 4 and 8 years of schooling. It seems reasonable to assume, therefore, that employers are indeed distinguishing between 'appropriate' and 'inappropriate' amounts of formal schooling. As a result, in the present model, formal education is measured as a dichotomous variable in which
4-8 years of schooling $=1$ and all other amounts $=0$. It is recognized, of course, that this is a simplistic procedure; future investigations using a larger sample would do well to adopt a more complex routine which more fully takes into account the evident curvilinear relationships between $\mathrm{FE}$ and the other elements in the framework.

\section{(2) Nonformal education}

As was suggested above, nonformal education not only encompasses a wide variety of different programs, but it probably also performs quite different functions with respect to the preparation of candidates for the labor market. It seems appropriate, therefore, to distinguish 'general' courses having a potential value for a number of employers from more 'specific' courses which are likely to be useful in a particular setting only. In accordance with ealier research conducted by Castro and Mello e Souza (1974), course duration was taken as an indicator of content specificity. It was assumed that courses lasting at least three months tend to be general while shorter courses are normally specific in that the latter can hardly have transmitted more than specialized and/or isolated skills. As a result, two different measures for nonformal education-general NFE (GNF) and specific NFE $(S N F)$-enter into the model. Similarly, courses which are related (as defined by the Cadastro Brasileiro de Ocupacoes, 1972) to the job being sought are distinguished from those geared to nonrelated occupational pursuits. And finally, the fact that employers may value NFE because of the time spent therein, because of the credential or certificate conferred, or because of merely having or not having had such an experience is taken into account via original variable operationaliza-

Table 1. Crosstabulation of occupational obtainment $(O O)$ by successfully completed years of formal cducation for $N=66$ applicants

\begin{tabular}{|c|c|c|c|c|c|c|c|c|c|c|c|c|c|}
\hline & \multicolumn{12}{|c|}{ Successfully completed years of formal education } & \multirow{2}{*}{$\begin{array}{l}\text { Row } \\
\text { total }\end{array}$} \\
\hline & 0 & 2 & 3 & 4 & 5 & 6 & 7 & 8 & 9 & 10 & 11 & 14 & \\
\hline \multicolumn{14}{|l|}{$O O$} \\
\hline Not hired & 1 & 1 & 2 & 6 & 16 & 5 & 4 & 7 & 3 & 3 & 3 & 2 & 53 \\
\hline Hired & 0 & 0 & 0 & 2 & 5 & 1 & 0 & 4 & 0 & 1 & 0 & 0 & 13 \\
\hline $\begin{array}{r}\text { Column } \\
\text { total }\end{array}$ & 1 & 1 & 2 & 8 & 21 & 6 & 4 & 11 & 3 & 4 & 3 & 2 & 66 \\
\hline
\end{tabular}


tions, although, for the immediate purposes here, a single 'best fit' measurement was selected, that being the total number of related courses taken. Meaningful outcomes pertaining to alternative NFE indicators are commented upon in a comparative fashion.

\section{(3) Informal education}

It is very difficult to arrive at direct measures for the amount of informal learning experiences an individual has had. In this study, attempts in this direction, based upon the personal recollections of the interviewed job applicants, had to be abandoned because of a problem with interviewer effects. There are two variables, however, that are widely used as indirect measures for this dimension: age $(A G E)$ and work experience $(W E)$. Both variables can be viewed as proxies for the informal accumulation of experience, including both intentional (educational) and non-intentional (socialization) processes. Among the various ways of operationalizing $W E$, the one chosen here as being the most relevant, was the total amount of time spent in industrial employment. Thus, nonindustrial work experience is omitted, and no distinction is made between industrial work experience within and outside the occupational area containing the job sought. However, an additional variable, 'residential background' $(R B G)$, was also included, which takes into account possible differences between the careers and socialization patterns of candidates from urban and rural backgrounds. $R B G$ is an ordinal variable ranging in value from 6 to 18 , whose lowest value refers to a rural background in the Northeast outside Bahia and whose highest valuc is associated with residence in the urban South/Southeast during one's formative years (i.e. from birth to age 15).

\section{(4) Context effects}

Based on what has been said above, at least two factors must be controlled for: the possible mitigating effects of personal recommendations $(R E)$ and the possibly diverging hiring practices of firms with varying degrees of technological complexity $(C E)$. In the first case, it was assumed that whenever someone already working in the firm had encouraged the applicant to appear in the personnel office, such recommendation would exist. In the case of $C E$, a variable was used to classify firms according to their size (taking into account five indicators, as specified by the Bahian Federation of Industry).

For the more technical details of data collection and variable coding, the reader is referred to the complete research report, available at INEP/MEC (Verhine and Lehmann, 1980).

Returning now to the question of how the variables are related to one another, it must be remembered that the majority of relevant information is of biographical nature, originally obtained via an instrument for the collection and analysis of retrospective life histories, developed by Blum et al. (1969). The data can now be structured such that variables are ordered as a sequence, in which temporally prior factors are seen as influencing subsequent variables, while, conversely, temporally later variables are viewed as having no effect on their antecedents. No such ordering is possible, though, in the cases of $R B G-A G E$ and $W E-$ $S N F$, meaning that no paths can be specified for these two pairs. The model structure following from these assumptions can best be visualized as a path diagram, like that presented in Fig. 1.

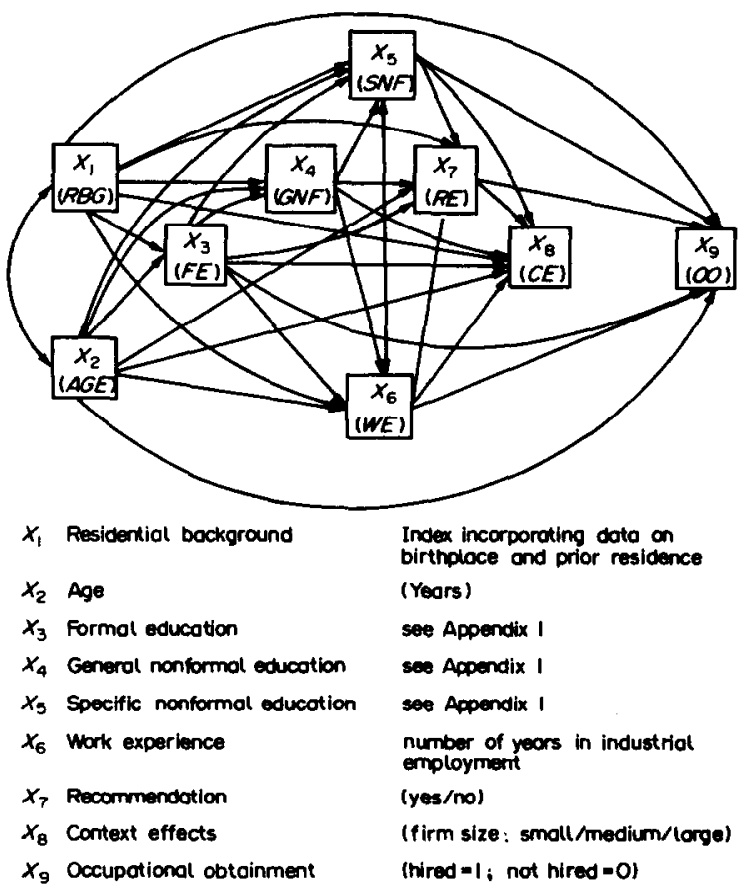

Fig. 1. Fully recursive model, establishing assumptions as to the relationships between variables related to occupational obtainment of industrial job applicants. 
Due to the predominantly exploratory character of this study, all the $\left(\frac{K}{2}\right)$ possibilities for the relations between two variables have been defined in this structure (i.e. a fully recursive model is used). Future studies, built upon a more substantial body of knowledge, could work more effectively by eliminating from the model such paths which for theoretical or empirical reasons can be assumed to stand for random effects only. At this point, however, such a priori restrictions do not appear justified, since in some cases the absence of effects will in itself represent an important contribution to empirical knowledge. It should also be noted that the application of more complex techniques of causal modelling could result in additional insights, namely procedures which can deal with latent constructs instead of just manifest variables. But again, it is difficult to justify such approaches at the present stage, considering the empirical and theoretical limitations of the study.

\section{DATA ANALYSIS}

Having specified in the previous section the structure of the causal model, data analysis is a matter of routine, easily performed on any computer for which a program for multiple regression analysis is implemented. In the present case, the REGRESSION component of the SPSS Version 6.02B available at the computer of the Federal University of Bahia, was used. The necessary control statements can be derived from the following equations which in turn are nothing but an algebraic equivalent of the diagram shown previously:

(1) $x_{3}=P_{31} x_{1}+P_{32} x_{2}+e_{3}$

(2) $x_{4}=P_{41} x_{1}+P_{42} x_{2}+P_{43} x_{3}+e_{4}$

(3) $x_{5}+=P_{51} x_{1}+P_{52} x_{2}+P_{53} x_{3}+P_{54} x_{4}+e_{5}$

(4) $x_{6}+=P_{61} x_{1}+P_{62} x_{2}+P_{63} x_{3}+P_{64} x_{4}+e_{6}$

(5) $x_{7}+=P_{71} x_{1}+P_{72} x_{2}+P_{73} x_{3}+P_{74} x_{4}+$ $P_{75} x_{5}+P_{76} x_{6}+e_{7}$

(6) $x_{8}+=P_{81} x_{1}+P_{82} x_{2}+P_{83} x_{3}+P_{84} x_{4}+$ $P_{85} x_{5}+P_{86} x_{6}+P_{87} x_{7}+e_{8}$

(7) $x_{9}+=P_{91} x_{1}+P_{92} x_{2}+P_{93} x_{3}+P_{94} x_{4}+$ $P_{95} x_{5}+P_{96} x_{6}+P_{97} x_{7}+P_{98} x_{8}+e_{9}$.

The path coefficients $P_{i j}$ were calculated as standardized regression coefficients (also known as $\beta_{i j}$ ), meaning that an increment of one standard deviation in $X_{j}$ 'causes' an increment of $\beta_{i j}$ standard deviations in $X_{i}$. In two cases, however, special considerations apply. The path coefficient $P_{12}$ between the two exogenous variables $R B G$ and $A G E$ is identical to the zero-order correlation $r_{12}$, and the path coefficient $P_{65}$, standing for a noncausal or uninterpretable relationship, is calculated as the correlation between the residuals in $x_{5}$ and $x_{6}$ (and hence, represents that part of the correlation $r_{65}$ which is unaccounted for by specified causal effects). The coefficients $e_{i}$ denote 'error', and these are merely the square root of the unaccounted variance in that multiple regression analysis which has $X_{i}$ as the dependent variable.

\section{RESULTS}

Univariate sample characteristics have already been fully documented elsewhere (Verhine and Lehmann, 1980, 1983), so that the present considerations can concentrate on the interpretation of these effects appearing in the path analysis. Nevertheless, a table of means, standard deviations and the correlation matrix of all the variables in the model (and a few alternative measures) will be given in the appendix, to enable the interested reader to perform secondary and/or comparative analyses.

The following table (Table 2) presents the path cocfficients found in accordance with the procedures specified above. No information pertaining to inference testing is provided, because such statistical procedures are inappropriate here. The use of dichotomous and ordinal variables precludes any utilization of $F$ statistics and the non-random method of selecting interviewees at personnel offices casts doubt on probability-based conclusions. Information on the explained variance (multiple $R^{2} ; \Delta R^{2}$ ) is given because, although these coefficients are meaningful only in so far as their order of listing is theoretically justified, this assumption is compatible with the temporal sequence upon which the entire model is based.

Before going into the details of the findings, the reader may find it useful to have a graphical representation of the effects as they are determined in the statistical analysis. In order to obtain a clearer notion of these effects 
Table 2. Multiple regression analyses for the prediction of seven background variables and occupational obtainment $(N=$ 64 applicants for skilled industrial blue-collar work from five factories in Salvador, Bahia)

\begin{tabular}{|c|c|c|c|c|c|c|c|}
\hline $\begin{array}{l}\text { Dependent } \\
\text { variable }\end{array}$ & $\begin{array}{l}\text { Independent } \\
\text { variable }\end{array}$ & d.f. & SS & $R^{2}$ & $\Delta R^{2}$ & $b$ & $\beta$ \\
\hline $\begin{array}{l}F E \\
\text { Residuals }\end{array}$ & $\begin{array}{l}R B G \\
A G E\end{array}$ & $\begin{array}{r}2 \\
61\end{array}$ & $\begin{array}{r}0.406 \\
10.531\end{array}$ & $\begin{array}{l}0.019 \\
0.037\end{array}$ & $\begin{array}{l}0.019 \\
0.018\end{array}$ & $\begin{array}{r}-0.019 \\
0.011 \\
0.742\end{array}$ & $\begin{array}{r}-0.104 \\
0.139\end{array}$ \\
\hline $\begin{array}{l}G N F \\
\text { Residuals }\end{array}$ & $\begin{array}{l}R B G \\
A G E \\
F E\end{array}$ & $\begin{array}{r}3 \\
60\end{array}$ & $\begin{array}{r}3.528 \\
18.185\end{array}$ & $\begin{array}{l}0.035 \\
0.138 \\
0.152\end{array}$ & $\begin{array}{l}0.035 \\
0.103 \\
0.014\end{array}$ & $\begin{array}{r}0.030 \\
-0.039 \\
0.166 \\
0.912\end{array}$ & $\begin{array}{r}0.120 \\
-0.347 \\
0.118\end{array}$ \\
\hline $\begin{array}{l}\text { SNF } \\
\text { Residuals }\end{array}$ & $\begin{array}{l}R B G \\
A G E \\
F E \\
G N F\end{array}$ & $\begin{array}{r}4 \\
59\end{array}$ & $\begin{array}{r}7.407 \\
116.343\end{array}$ & $\begin{array}{l}0.001 \\
0.052 \\
0.055 \\
0.060\end{array}$ & $\begin{array}{l}0.001 \\
0.051 \\
0.003 \\
0.005\end{array}$ & $\begin{array}{r}0.003 \\
0.071 \\
-0.213 \\
0.183 \\
-1.082\end{array}$ & $\begin{array}{r}0.005 \\
0.266 \\
-0.063 \\
0.075\end{array}$ \\
\hline $\begin{array}{l}W E \\
\text { Residuals }\end{array}$ & $\begin{array}{l}R B G \\
A G E \\
F E \\
G N F\end{array}$ & $\begin{array}{r}4 \\
59\end{array}$ & $\begin{array}{l}582.147 \\
472.337\end{array}$ & $\begin{array}{l}0.096 \\
0.539 \\
0.551 \\
0.552\end{array}$ & $\begin{array}{l}0.096 \\
0.443 \\
0.012 \\
0.001\end{array}$ & $\begin{array}{r}-0.236 \\
0.534 \\
1.056 \\
0.223 \\
-5.882\end{array}$ & $\begin{array}{r}-0.135 \\
0.682 \\
0.108 \\
0.032\end{array}$ \\
\hline Residuals & $\begin{array}{l}R B G \\
A G E \\
F E \\
G N F \\
S N F \\
W E\end{array}$ & $\begin{array}{r}6 \\
57\end{array}$ & $\begin{array}{l}2.120 \\
9.880\end{array}$ & $\begin{array}{l}0.060 \\
0.080 \\
0.102 \\
0.138 \\
0.163 \\
0.177\end{array}$ & $\begin{array}{l}0.060 \\
0.020 \\
0.022 \\
0.036 \\
0.025 \\
0.014\end{array}$ & $\begin{array}{r}-0.064 \\
0.009 \\
-0.156 \\
0.167 \\
-0.053 \\
0.019 \\
1.129\end{array}$ & $\begin{array}{r}-0.344 \\
0.113 \\
-0.168 \\
0.224 \\
-0.172 \\
-0.176\end{array}$ \\
\hline Residuals & $\begin{array}{l}R B G \\
A G E \\
F E \\
G N F \\
S N F \\
W E \\
R E\end{array}$ & $\begin{array}{r}7 \\
56\end{array}$ & $\begin{array}{r}7.403 \\
24.346\end{array}$ & $\begin{array}{l}0.046 \\
0.048 \\
0.063 \\
0.086 \\
0.142 \\
0.148 \\
0.233\end{array}$ & $\begin{array}{l}0.046 \\
0.003 \\
0.015 \\
0.023 \\
0.058 \\
0.006 \\
0.085\end{array}$ & $\begin{array}{r}0.097 \\
-0.007 \\
-0.145 \\
0.086 \\
0.154 \\
0.029 \\
0.523 \\
1.269\end{array}$ & $\begin{array}{r}0.319 \\
-0.050 \\
-0.085 \\
0.070 \\
0.305 \\
0.169 \\
0.322\end{array}$ \\
\hline Residuals & $\begin{array}{l}R B G \\
A G E \\
F E \\
G N F \\
S N F \\
W E \\
P E \\
C E\end{array}$ & $\begin{array}{r}8 \\
55\end{array}$ & $\begin{array}{l}2.472 \\
7.278\end{array}$ & $\begin{array}{l}0.002 \\
0.037 \\
0.039 \\
0.131 \\
0.226 \\
0.226 \\
0.252 \\
0.254\end{array}$ & $\begin{array}{l}0.002 \\
0.036 \\
0.052 \\
0.042 \\
0.094 \\
0.000 \\
0.026 \\
0.002\end{array}$ & $\begin{array}{r}0.009 \\
0.024 \\
0.208 \\
0.137 \\
-0.085 \\
0.001 \\
0.147 \\
0.026 \\
-0.849\end{array}$ & $\begin{array}{r}0.051 \\
0.317 \\
0.221 \\
0.204 \\
-0.301 \\
0.009 \\
0.163 \\
0.046\end{array}$ \\
\hline
\end{tabular}

Partial correlation $S N F-W E: r_{65.1234}=-0.063$

to which some meaningful interpretation can be attached, any path with $\left|P_{i j}\right|<0.10$ is omitted from the graph (see Fig. 2).

In trying to relate these findings to the theoretical issues at stake, it is helpful to interpret them in accordance with their position in the temporal sequence. This procedure will make it possible to reconstruct stepwise the biographical background of the interviewed applicants for skilled jobs, thus assessing the relative importance of each component in the entire network of possible causal relations. Many of these observed relationships are consistent with well estab- 


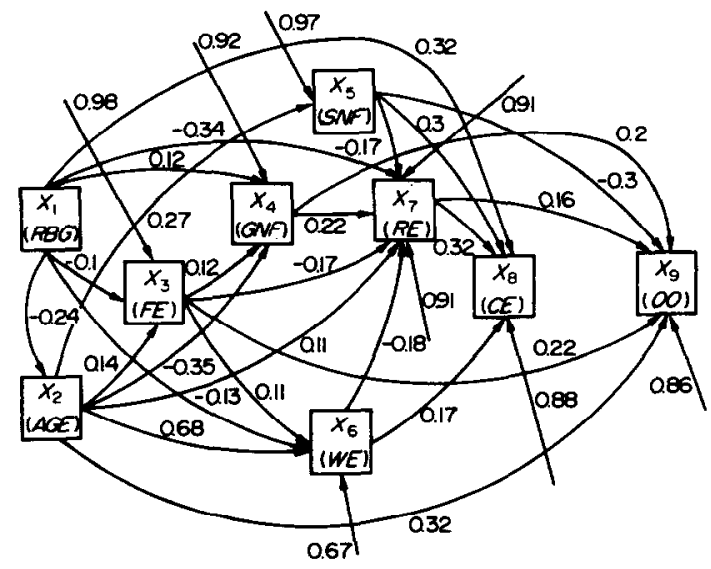

Fig. 2. Fully recursive model, giving the path coefficients related to occupational obtainment of industrial job applicants (paths with $|p|<0.10$ omitted).

lished knowledge; others which are at first sight contrary to expectations serve to highlight the complex nature of relevant processes, and thus demonstrate the importance of taking intervening effects into account.

\section{(1) Formal education (FE)}

It should be remembered that formal education in the present analysis is a dichotomous variable, distinguishing between 'appropriate' (4-8 years) and 'inappropriate' (less than 4 years and more than 8 years) amounts of schooling. This non-linear measure of formal cducation accounts for the observed negative relationship between FE and residential background. Since in the sample candidates with urban origins have more schooling than their rural-born counterparts, many of the former may be considered over-qualified by $\mathrm{em}$ ployers. As can be seen from Appendix 2, if formal education is measured via the more traditional 'years of successful schooling' $(F E Y)$, the correlation between this learning mode and residential background is +0.46 (with the respective $P_{31}$ being +0.43 ).

The unexpected positive relationship between formal education and age can be interpreted in a similar fashion. While younger adults - due to a development of schooling opportunities over time - tend to have had more formal education than the older candidates (the respective cuefficients for $A G E /$ $F E Y$ being $r_{32}=-0.24$ and $P_{32}=-0.18$ ), the evident practical effect of such extended schooling is to make the younger individual unattractive to employers, at least on the skilled manual level. So it is the older applicant who tends to have the 'appropriate' amount of schooling.

In both above mentioned cases the observed effects are comparatively small and should not be overemphasized. It is noteworthy, though, that they are operating in the same direction and mutually reinforce each other, as can be seen if one adds the indirect effect of $P_{21}{ }^{*} P_{32}$ $=-0.03$ to the direct effect of $P_{31}$ or the indirect effect of $P_{21}{ }^{*} P_{31}=+0.02$ to the direct effect of $P_{32}$. These results clearly suggest that migrant workers and older applicants, because of limited access to formal education, are more likely than their urban/young competitors to have 'proper' amounts of schooling.

\section{(2) General nonformal education (GNF)}

As outlined earlier, this term refers to long courses of at least three months duration, in their majority provided by SENAI (although long firm-sponsored and non-SENAI courses do appear in the sample). They are considered here only if they were geared to an occupational area related to the job being sought. It should be noted, though, that there is no substantial difference in observed outcomes when alternative measures of general nonformal education are used (i.e. total rather than just job-related $G N F$ and/or the amount of time rather than the number of courses).

The results, obviously, are consistent with expectations. General nonformal education is more frequent among urban applicants than it is among migrants, and it is much more seldom found among older candidates than among their younger counterparts, other things being equal. This suggests a growing impact of activities in the field of vocational training, especially on the part of SENAI, and it also shows that so trained young people are looking for jobs on the skilled level. Indeed, $38 \%$ of all applicants have had at least one $G N F$ course, with the percentage among younger workers and those born and raised in urban areas even higher.

The only surprising finding pertaining to general nonformal education is the weakness of the association between this factor and the variable 'formal education'. Since the SENAI youth apprenticeship course requires 4 years of schooling for admittance, one might expect a 
strong positive relationship between the two variables. It appears, though, that some of those who enter this course have failed to comply with the minimal requirements while others continue, concomitantly and thereafter, with their formal schooling, reaching levels considered 'inappropriate' by employers. The fact that both tendencies are operative is indicated by the fact that the linkage between general nonformal education and formal education is only slightly more pronounded when the linear measure of schooling (successfully completed years) is used $\left(P_{43}=+0.16\right)$.

\section{(3) Specific nonformal education (SNF)}

This variable considers only very short, occupationally related courses. The number of such courses is seemingly a good indicator of the quantity of job relevant skills an applicant possesses.

Although at this point specific nonformal education is discussed only with respect to its antecedents (its functions in the labor market are left for later analysis), fundamental differences between this factor and general nonformal education $(G N F)$ are already apparent. For instance, the relationship between SNF and residential background is virtually nil, whereas there is an urban predominance in the case of GNF. Thus, unlike $G N F, S N F$ courses are experienced as often by migrants as by native urban applicants. The migrant's $S N F$ courses, on the other hand, tend to have been shorter than those taken by their urban competitors, a fact apparent from an examination of the amount the two groups spent in $S N F$. In interpreting these outcomes, it is helpful to remember that generally, the shorter the course, the lower the cost, both to sponsoring agencies and to matriculants (especially, in the case of the latter, when earnings foregone are considered). As a result, specific nonformal education tends to be more widely available than is general nonformal education, and it is more readily accessible to those with minimal economic resources. Thus, it seems reasonable to conclude that $S N F$ serves as a substitute for longer basic vocational training, at least among groups who are most disadvantaged. Analysis of other paths affecting $S N F$ supports this viewpoint. It is found, for example, that $S N F$ is concentrated among older applicants $\left(P_{52}=\right.$ $+0.27)$ and that it is inversely - albeit weakly-associated with formal education $\left(P_{53}=-0.06\right)$. Also, there is no strong relationship between $S N F$ and $G N F\left(P_{54}=\right.$ +0.08 ), which means that theoretical complementarities between general and specific instruction are not, in practice, taken advantage of, at least within the sample of skilled job seekers under consideration. Clearly, the distinction made in this paper between long and short nonformal education experiences is valid; the two training modes serve different clienteles and therefore relate very differently to the other components in the model.

\section{(4) Work experience (WE)}

The number of years spent in industrial employment might, at first glance, seem to be highly related to what was measured by the specific nonformal education variable, and if this were correct, the structural model here used would not be appropriately specified. The zero-order correlation $\left(r_{65}=+0.12\right)$ indicates, however, that the mere possession of industrial employment, at least in this group of applicants, is not necessarily associated with specializing training. This becomes even more evident when spurious effects are eliminated from this correlation. The direct interaction between specific nonformal education and work experience is only $P_{65}=-0.06$, a finding consistent with presupposed model properties.

The variable 'work experience' is structurally related to its antecedents in much the expected manner. When considering its relationship with residential background, it is again found that selection effects related to migratory movement are involved. The negative sign and the moderate value of $P_{61}=-0.13$ show that 'migrant workers' (here defined as individuals who have stayed in the interior until at least 15 years of age) accumulate industrial experience, many times via construction work, while urban applicants tend to have less, perhaps because tertiary sector activities, so frequent in large cities, are not considered 'industrial work experience' in this study.

The close relationship between work experience and age $\left(P_{62}=+0.68\right)$ is not unexpected. The association is of considerable theoretical importance, however, since there is much debate in the literature over whether or not the two indicators are really measures of different phenomena. Mincer, for example, argues that the two variables stand for distinct aspects of 
informal learning processes: while age primarily measures physiological and psychological effects of maturation, work experience is seen as an indicator for informal on-the-job learning (Mincer, 1974). Mincer fails, though, to include both factors in his now famous human capital equations. But, as will be seen below, there are indeed substantial differences between the two measures with respect to their functions in the labor market. And, in any event, it does not seem reasonable to exclude one variable from the analysis in favor of the other (as was done in Velloso, 1975), since collinearity between the two is not high enough to preclude mutually independent effects on the variables later in the sequence.

With respect to the relationship between work experience and formal education, the reader is reminded once again of the meaning of formal education in the present analysis. In many previous studies (e.g. Mincer, 1974; Simmons, 1974; Velloso, 1975), work experience and formal education were found to be negatively related, and this is also the case for the present data when length of formal education (variable $F E Y$ ) is used in the analysis (rendering in this case $P_{63}=-0.16$ ). When the curvilinearity of formal education effects is considered, however, as is done here by distinguishing 'appropriate' from 'inappropriate' amounts of school experience, a slightly positive relationship is evident $\left(P_{63}=+0.11\right)$. Or, said in another way, those individuals with 'appropriate' formal education tend to be among those with the most work experience because they left school earlier than did a substantial portion of those with 'inappropriate' formal instruction.

The absence of any significant relationship between work experience and general nonformal education is noteworthy. Although the zero-order correlation $r_{64}=-0.23$ is considerable, virtually all of this covariation is accounted for by age effects $\left(P_{42}{ }^{*} P_{62}=\right.$ -0.23 ). It follows from this that general nonformal education is in fact providing the labour market with an alternative to job search patterns. While traditionally applicants have perceived their qualifications for skilled industrial work in terms of their informally acquired on-the-job learning, there is now a second, younger group of applicants for such positions whose qualification pool derives from participation in general vocational training. With this type of background becoming more frequent over time, one should expect a positive relation between general nonformal education and work experience to emerge in the future, assuming that applicants, so trained, will enter quickly ino the labor market and be less affected by unemployment than their competitors without such training.

\section{(5) Recommendation (RE)}

When considering the factors which influence the existence/nonexistence of a recommendation for a given applicant, it becomes apparent that two functions of this instrument for matching supply and demand on the labor market can be distinguished. As already noted, recommendation may serve both as a substitute for a lack of convincing qualifications and as a mechanism for endorsing applicants who do have such a 'desirable' background. Both functions appear to be present in the data. On the one hand, one finds that $R E$ is positively related with age and negatively associated with work experience. It is also negatively linked to residential background $\left(P_{71}=\right.$ -0.34 ), which suggests that migrants from the interior tend to seek access to industrial employment through persons already working in factories. On the other hand, $R E$ is also associated with factors which denote advanced levels of formal qualification, such as years of successful schooling $(F E Y)\left(P_{73}=+0.12\right)$ and general nonformal education $\left(P_{74}=\right.$ $+0.22)$. The latter relationship may be a result of the fact that many general vocational training courses include a factory apprenticeship component, which enables enrollees to make in-firm contacts.

The negative relationship between recommendation and specific nonformal education $\left(P_{75}=-0.17\right)$ is difficult to interpret meaningfully at this stage. If specific nonformal education is perceived as an indicator of marketable skill acquisition, the negative sign means that here, as seen with respect to work experience and residential background, recommendations function to compensate for a perceived lack of qualification. If, however, specific nonformal education is viewed as too specializing and thus non-transferable, recommenders may be acting in accordance with employer criteria, thereby reinforcing prevalent screening outcomes. Which of these two interpretations is correct will be seen shortly, 
when the impact of specific nonformal education on the actual acquisition of skilled-level jobs is discussed.

\section{(6) Employment context (CE)}

This factor, measured here as firm size, functions primarily as a control variable, but the findings from the respective multiple regression analyses are meaningfully interpretable, inasmuch as they reflect selection processes prior to the actual decision to employ. It can be seen, in this respect, that applicants at big firms are different from those found at small firms. There is a clear tendency for urban candidates to look for employment in larger firms $\left(P_{81}=+0.32\right)$, while migrants will tend to do so if a recommending person is available (indirect effect $P_{71}{ }^{*} P_{87}=-0.11$ ). Workers with higher amounts of industrial work experience, independent of age, are found in larger firms' personnel offices $\left(P_{86}=\right.$ +0.17 ), a phenomenon possibly reflecting a tendency among this group to move over time into firms presumed to offer better employment conditions. Recommendations are also more frequent in the larger establishments $\left(P_{87}\right.$ $=+0.32$ ), which may be due both to a greater likelihood of knowing somebody in a larger firm and to an attractiveness on the part of big companies which leads potential applicants to look for help in their attempt to obtain access.

The differences between larger and smaller firms are also apparent with respect to applicants' nonformal education experience. If it can be assumed that specific courses are mostly experienced in larger firms (either directly sponsored by the factory or indirectly by designating workers to attend SENAI courses), the positive influence of specific nonformal education on employment context $\left(P_{85}=+0.30\right)$ becomes comprehensible as a tendency among workers from big firms to stay in an essentially similar, attractive setting. In principle, this is also true for the relationship between general nonformal education and employment context. Although the direct effect is rather small $\left(P_{84}=+0.07\right)$, there is also a clear indirect effect via recommendation $\left(P_{74} * P_{87}=+0.07\right)$, which must be added to the former. The notion of an information effect associated with participation in SENAI-type programs (Puryear, 1979) seems to be supported by the present data. In summary, it seems reasonable to interpret the intervening influence of firm size as reflecting a tendency among job seekers to associate larger firms with greater career opportunities. This interpretation is consistent with observed influences of biographical antecedents on the workers' decisions to apply for work in a given employment context.

\section{(7) Job acquisition (OO)}

It is this stage of analysis which is most directly related to educational policy-making, although the previous steps have been important in depicting the entire job acquisition process. This depiction should make it possible to arrive at a more complete assessment of the relative weight given to the various forms of educational experience by the employer in his decision to hire or reject applicants for industrial employment on the skilled level.

As expected, there is virtually no direct influence of residential background on job acquisition $\left(P_{91}=+0.05\right)$, although some of the previous analyses have shown that migrants from the interior adopt a distinct pattern of moving into the industrial labor force. But any direct effect would be equivalent to an employer's preference for a certain residential background, and while there may be traits among migrants to make this group attractive to the firms (possibly a lower level of wage aspiration), there are probably others (such as an unfamiliarity with industrial settings) which offset such advantages.

Informal learning does seem to play a role, however. It may seem surprising that age is a fairly good predictor for job acquisition $\left(P_{92}=\right.$ $+0.32)$, while work experience shows no direct influence whatsoever $\left(P_{96}=+0.01\right)$. In trying to explain this phenomenon, one has to remember that age is measuring very general processes of informal learning and/or maturation, whereas work experience reflects specific learning processes which may not be relevant (at least in the mind of the employer) to the job being sought. In other words, the informal onthe-job learning obtained via time working does not appear to be transferable; it may be a factor in job advancement within a given firm but it does not add to the worker's 'marketability' in the 'external' labor market.

As far as the influence of formal education is concerned, the positive impact $\left(P_{93}=+0.22\right)$ is in accordance with the distinction between 'appropriate' and 'inappropriate' amounts of 
schooling. When 'years of school successfully completed' (variable $F E Y$ ) is used, the effect of schooling is negative $\left(P_{93}=-0.04\right)$, a consequence, perhaps, of academic overqualification, as discussed earlier in this paper. Of course, other explanations for the observed findings are possible, but the over-qualification hypothesis seems to these investigators to be the interpretation most consistent with the existing literature. It would be wrong, however, to view the present findings as an argument against more and better schools. On the contrary, the fact that one seems to need at least 4 years of schooling serves to highlight the importance of universalizing first level formal instruction. Also, it should be remembered that the results apply only to the skilled manual level at a specific moment in time. These findings, nevertheless, are of theoretical interest because, in contrast to the implications of several well known education/labor market paradigms (i.e. human capital and job competition models), they suggest that more formal education is not automatically associated with a higher probability of employment.

With respect to nonformal education, the results illustrate the importance of distinguishing between 'specific' and 'general' training experience when examining the job acquisition process. The path linking specific nonformal education to the dependent variable is negative $\left(P_{95}=-0.30\right)$, indicating that specialization of this nature does not help and, indeed, may even hinder workers in the labor market. This negative direct effect is aggravated by an indirect effect via recommendation $\left(P_{75} * P_{97}\right.$ $=-0.03)$. General nonformal education, on the other hand, does increase chances for employment $\left(P_{94}=+0.20\right)$, and, again, the direct effect (in this case, positive) is reinforced by an indirect effect via recommendation $\left(P_{74}{ }^{*}\right.$ $\left.P_{97}=+0.04\right)$. Thus, it appears that employers, when hiring skilled manual labour, tend to value learning experiences which are widely applicable and look disfavorably upon those which are likely to be useful in a particular setting only. This conclusion, however, is tempered by another finding. Analysis reveals that when nonformal education variables are altered to include courses which are unrelated to the job sought, the respective path coefficients decrease $\left(P_{94}=+0.17 ; P_{95}=\right.$ -0.31 , which is substantial considering that $91 \%$ of all courses encountered in the sample are classified as related. This suggests that the degree of course generality preferred is limited. The nonformal education learning content which contributes to job acquisition seems to be that which can be applied to a variety of firms but is directly geared to specific occupations.

Recommendations, finally, also emerge as a significant factor in the job obtainment process $\left(P_{98}=+0.16\right)$. As already suggested, this contribution represents more than merely a residual of traditionalism in Bahian society. While it is true that recommendations provide a substitute for certain 'inappropriate' qualifications (e.g. formal education), they also apparently serve to funnel 'apt' candidates into employment, probably by selectively providing the unemployed with information on job openings. In this sense, recommendations constitute both a legitimate and an effective instrument for matching supply and demand in the industrial labor market.

\section{CONCLUSION}

Using data derived from a sample of male applicants for skilled manual work interviewed in Bahia's Centro Industrial de Aratu, this paper has offered a model of the job obtainment process experienced by factory workers. In so doing, it has sought to provide information on the economic significance of alternative modes of education and, in addition, it has attempted to illustrate the usefulness of path analysis in assessing the direct and indirect contributions of potential determinants of employment. The results of the study reveal that informal, nonformal and formal education all excrt some impact on job obtainment. The influence of formal education, however, is evident only when the variable is measured in a non-linear format which distinguishes between 'appropriate' and 'inappropriate' amounts of schooling. The positive effect of nonformal education, in turn, is limited to training which is general in nature. Specific nonformal education relates negatively with employment, suggesting that extreme specialization may reduce workers' job opportunities.

The observed outcomes are useful in that they shed light on the 'training vs trainability' debate. In hiring, employers obviously prefer candidates with evidence of general learning 
contents, as indicated by their preference for age over work experience, primary level over secondary level formal schooling, and general over specific training. Such general learning contents normally include both basic, broadly applicable skills and behavioural traits appropriate to bureaucratic industrial production, which are exactly the ingredients conventionally believed to comprise 'trainability'. Further analysis, however, suggests that there may be more than just trainability at stake. As seen, employers favour nonformal educational experiences which are related to the job sought. Thus, a modicum of know-how which is directly pertinent to the occupation in question is apparently desirable, a factor which is, at best, only partially explainable by the 'trainability' concept. Clearly, in future studies, attention must be given to precisely specifying both the contents of courses and the perceptions/opinions of employers regarding the job acquisition process. Only then will it be possible to determine the learning-related characteristics viewed as relevant in the marketplace and the reasons behind such preferences.

In sum, there is a need for much additional research on the present topic. It seems reasonable to conclude, however, that policy makers should not attempt to substitute vocational training for formal education. Rather, they should seek to provide universal schooling until at least the end of the first level plus make available out-of-school vocational training opportunities in which basic, generalizable learning contents are emphasized.

Acknowledgement-The authors would like to thank the Instituto Nacional de Estudos e Pesquisas Educacionais (INEP) for funding the research on which this article is based. They are also indebted to Dr J. L. Buschman, of Michigan State University, for his contribution to the planning and coordination of the study. During portions of the investigation, $R$. Lehmann and $R$. Verhine received financial support from the German Academic Exchange Service (DAAD) and the Conselho Nacional de Desenvolvimento Cientifico e Tecnologico (CNPq), respectively.

\section{REFERENCES}

Averch, H. A. et al. (1972) How Effective is Schooling? A Critical Review and Synthesis of Research Findings. Rand, Santa Monica, CA.
Becker, G. S. (1964) Human Capital. National Bureau of Economic Research, New York.

Berg, I. (1970) Education and Jobs. Praeger, New York.

Blalock, H. M. (ed.) (1971) Causal Models in the Social Sciences. Aldine, Chicago.

Blau, P. and Duncan, O. D. (1967) The American Occupational Structure. John Wiley, New York.

Blaug, M. (1972) The correlation between education and earnings: what does it signify? Higher Education, 1, 53-76.

Blum, Z. D., Karweit, N. L. and Sorenson, A. B. (1969) A method for the collection and analysis of retrospective life histories. Johns Hopkins University, Report No. 48, Baltimore, MD.

Bourdieu, P. and Passeron, J. C. (1970) La Reproduction. Les Editions de Minuit, Paris.

Bowles, S. (1971) Unequal education and the reproduction of the social division of labor. Review of Radical Political Economics 3, 28-47.

Brembeck, C. S. and Thompson, T. J. (1973) New Strategies for Educational Development. D.C. Heath, Lexington, MA.

Buschman, J. L. (1977) Adult literacy and factory employment: a study of MOBRAL courses in Brazil. Unpublished Ph.D. Dissertation, University of Florida.

Cadastro Brasileiro de Ocupacoes. (1972) Ministerio de Trabalho e Bem Estar Social, Brasilia.

Carnoy, M. (1967) Rates of return to schooling in Latin America. Journal of Human Resources II, 359-374.

Castro, C. M. (1970) Investment in education in Brazil: a study of two industrial communities. Unpublished Ph.D. Dissertation, Vanderbilt University.

Castro, C. M. and Mello e Souza, A. (1974) Mao de Obra Industrial no Brasil. IPEA/INPES, Rio de Janeiro.

Coilins, R. (1971) Functional and conflict theories of educational stratification. American Sociological Review 36, 1002-1019.

Coombs, P. H. (1968) The World Educational Crises. Oxford University Press, New York.

Duncan, O. D. (1975) Introduction to Structural Equation Models. Academic Press, New York.

Edfelt, R. B. (1975) Occupational education and training: the role of large private industry in Brazil. In Educational Alternatives in Latin America (edited by La Belle, T. J.) pp. 384-413. UCLA Latin American Center, Los Angeles, CA.

Harbinson, F. H. and Myers, C. A. (1964) Education, Manpower and Economic Growth. McGraw-Hill, New York.

Jencks, C. et al. (1972) Inequality: A Reassessment of the Effect of Family and Schooling in America. Basic Books, New York.

King, K. (1980) Education and self-employment. In Education, Work and Employment-II (edited by UNESCO) pp. 219-283. International Institute of Planning, Paris.

LaBelle, T. J. (1976) Nonformal Education and Social Change in Latin America. UCLA Latin America Center, Los Angeles, CA.

LaBelle, T. J. (1975) The impact of nonformal education on income in industry: Cuidad Guyana, Venezuela. In Educational Alternatives in Latin America (edited by LaBelle, T. J.) pp. 160-190.

Leeds, A. (1964) Brazilian careers and social structure: an evolutionary model and case history, American Anthropologist, 66, 1321-1347. 
Lehmann, R. H. and Verhine, R. E. (1982) Contributions of formal and nonformal education to the obtainment of skilled industrial employment in northeastern Brazil. International Journal of Educational Development 2, 374-390.

Menezes, M. (1987) Educacao e o Mercado de Trabalho: um estudo sobre a relacao entre escolaridade e aquisicao de emprego no comercio. Unpublished Masters Thesis, Mestrado em Educacao, Universidade Federal de Bahia.

Mincer, J. (1974) Schooling, Experience and Earnings. National Bureau of Economic Research, New York.

Paulston, R. (1972) Non-Formal Education: An Annotated International Bibliography. Praeger, New York.

Puryear, M. (1979) Vocational training and earnings in Colombia: does a Sena effect exist? Comparative Education Review 23, 283-292.

Schulz, T. (1961) Investment in human capital. American Economic Review 51, 1-17.

Simmons, J. (1973) The determinants of earnings: towards an improved model. IBRD Bank Staff Working Paper No. 173.

Thurow, L. (1975) Generating Inequality. Basic Books, New York.

Velloso, J. R. (1975) Human capital and market segmentation: an analysis of the distribution of earnings in Brazil, 1970. Unpublished Ph.D. Dissertation, Stanford University.

Verhine, R. E. (1982) Educacao e mercado de trabalho: perspectivos alternativos e suas implicacoes para o problema de pobreza. In Populacao, Educacao, Emprego, Vol. 2, (edited by Castro, N. A. and Flavio, L. Q.), pp. 85-130. Centro de Recursos Humanos, UFBA, Salvador, BA.

Verhine, R. E. and Lehmann, R. H. (1980) Educação básica e entrada em empregos industriais. Universidade Federal da Paraiba/Instituto Nacional de Estudos e Pesquisas Educacionais, Joāo Pessoa.

Verhine, R. E. and Lehmann, R. H. (1985) Obtencao de emprego industrial como funcao de educacao naoformal. Cadernos de Pesquisa 47, 53-63. 
EDUCATION AND INDUSTRIAL JOB ACQUISITION IN BRAZIL

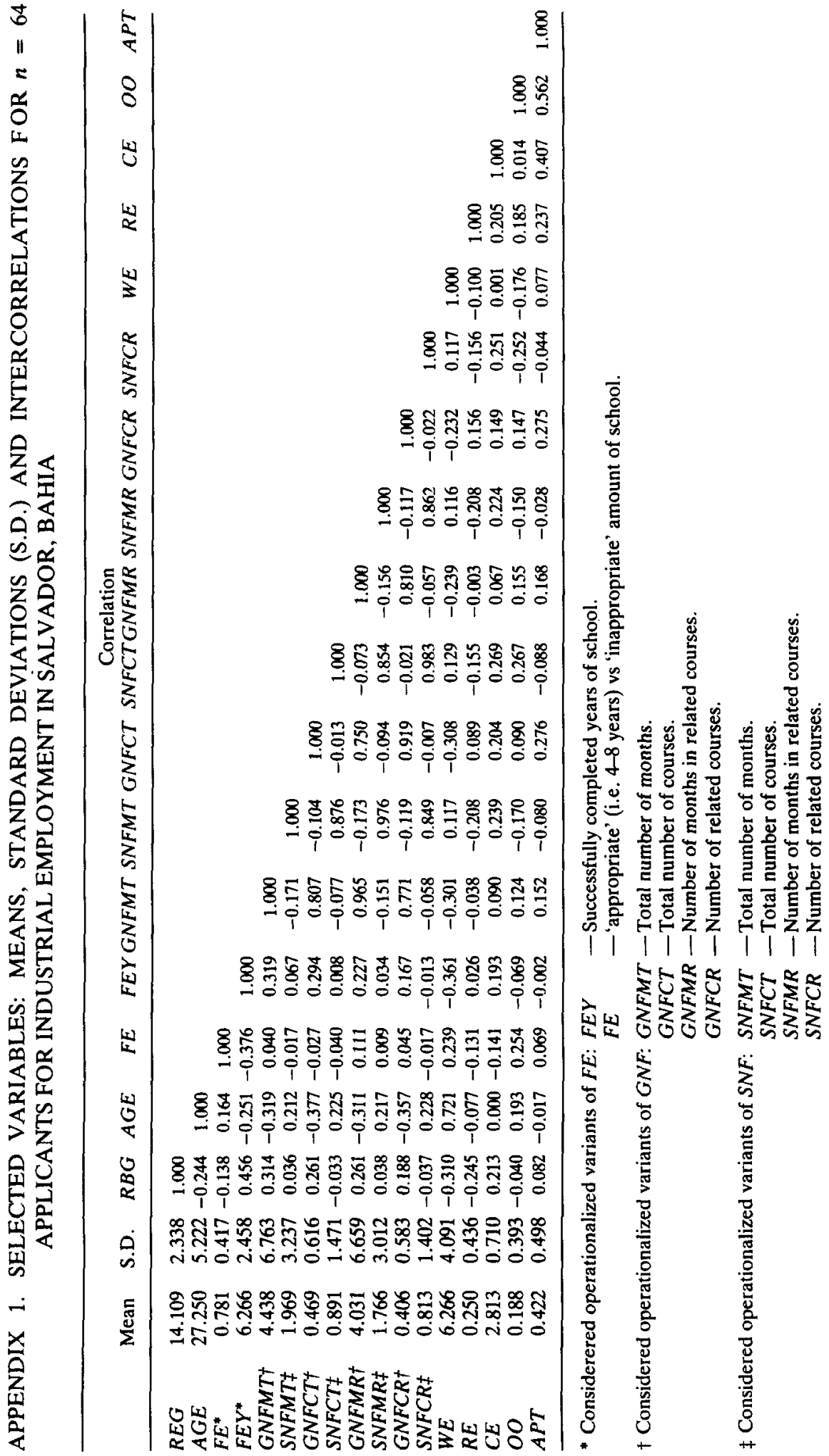


APPENDIX 2.

ALTERNATIVE REGRESSION TABLE: MULTIPLE REGRESSION ANALYSES FOR THE PREDICTION OF SEVEN BACKGROUND VARIABLES AND OCCUPATIONAL OBTAINMENT $(n=64$ APPLICANTS FOR SKILLED INDUSTRIAL BLUE-COLLAR WORK FROM FIVE FACTORIES IN SALVADOR, BAHIA); FORMAL EDUCATION MEASURED IN 'SUCCESSFULLY COMPLETED YEARS OF SCHOOL' (FEY)

\begin{tabular}{|c|c|c|c|c|c|c|c|}
\hline $\begin{array}{l}\text { Dependent } \\
\text { variable }\end{array}$ & $\begin{array}{l}\text { Independent } \\
\text { variable }\end{array}$ & d.f. & SS & $R^{2}$ & $\Delta R^{2}$ & $b$ & $\beta$ \\
\hline $\begin{array}{l}F E Y \\
\text { Residuals }\end{array}$ & $\begin{array}{l}R B G \\
A G E\end{array}$ & $\begin{array}{r}2 \\
61\end{array}$ & $\begin{array}{r}87.152 \\
293.332\end{array}$ & $\begin{array}{l}0.208 \\
0.229\end{array}$ & $\begin{array}{l}0.208 \\
0.021\end{array}$ & $\begin{array}{r}0.442 \\
-0.070 \\
1.945\end{array}$ & $\begin{array}{r}0.420 \\
-0.149\end{array}$ \\
\hline $\begin{array}{l}G N F \\
\text { Residuals }\end{array}$ & $\begin{array}{l}R B G \\
A G E \\
F E Y\end{array}$ & $\begin{array}{r}3 \\
60\end{array}$ & $\begin{array}{r}2.988 \\
18.440\end{array}$ & $\begin{array}{l}0.035 \\
0.138 \\
0.140\end{array}$ & $\begin{array}{l}0.035 \\
0.103 \\
0.002\end{array}$ & $\begin{array}{r}0.022 \\
-0.036 \\
0.011 \\
1.014\end{array}$ & $\begin{array}{r}0.088 \\
-0.324 \\
0.045\end{array}$ \\
\hline Residuals & $\begin{array}{l}R B G \\
A G E \\
F E Y \\
G N F\end{array}$ & $\begin{array}{r}4 \\
59\end{array}$ & $\begin{array}{r}7.125 \\
116.625\end{array}$ & $\begin{array}{l}0.001 \\
0.052 \\
0.054 \\
0.058\end{array}$ & $\begin{array}{l}0.001 \\
0.051 \\
0.002 \\
0.004\end{array}$ & $\begin{array}{r}-0.004 \\
0.070 \\
0.025 \\
0.156 \\
-1.264\end{array}$ & $\begin{array}{r}-0.006 \\
0.261 \\
0.045 \\
0.065\end{array}$ \\
\hline Residuals & $\begin{array}{l}R B G \\
A G E \\
F E Y \\
G N F\end{array}$ & $\begin{array}{r}4 \\
59\end{array}$ & $\begin{array}{l}591.928 \\
462.557\end{array}$ & $\begin{array}{l}0.096 \\
0.539 \\
0.559 \\
0.561\end{array}$ & $\begin{array}{l}0.096 \\
0.443 \\
0.020 \\
0.002\end{array}$ & $\begin{array}{r}-0.140 \\
0.533 \\
-0.270 \\
0.369 \\
-4.725\end{array}$ & $\begin{array}{r}-0.080 \\
0.680 \\
-0.162 \\
0.053\end{array}$ \\
\hline Residuals & $\begin{array}{l}R B G \\
A G E \\
F E Y \\
G N F \\
S N F \\
W E\end{array}$ & $\begin{array}{r}6 \\
57\end{array}$ & $\begin{array}{r}1.942 \\
10.058\end{array}$ & $\begin{array}{l}0.060 \\
0.080 \\
0.098 \\
0.124 \\
0.148 \\
0.162\end{array}$ & $\begin{array}{l}0.060 \\
0.020 \\
0.018 \\
0.027 \\
0.023 \\
0.014\end{array}$ & $\begin{array}{r}-0.070 \\
0.008 \\
0.022 \\
0.147 \\
-0.052 \\
-0.019 \\
0.978\end{array}$ & $\begin{array}{r}-0.375 \\
0.088 \\
0.123 \\
0.196 \\
-0.166 \\
-0.179\end{array}$ \\
\hline Residuals & $\begin{array}{l}R B G \\
A G E \\
F E Y \\
G N F \\
S N F \\
W E \\
R E\end{array}$ & $\begin{array}{r}7 \\
56\end{array}$ & $\begin{array}{r}7.407 \\
24.343\end{array}$ & $\begin{array}{l}0.046 \\
0.048 \\
0.062 \\
0.079 \\
0.138 \\
0.144 \\
0.233\end{array}$ & $\begin{array}{l}0.046 \\
0.003 \\
0.014 \\
0.017 \\
0.058 \\
0.006 \\
0.090\end{array}$ & $\begin{array}{r}0.089 \\
-0.008 \\
0.028 \\
0.065 \\
0.156 \\
0.031 \\
0.532 \\
1.126\end{array}$ & $\begin{array}{r}0.292 \\
-0.059 \\
0.095 \\
0.054 \\
0.308 \\
0.178 \\
0.327\end{array}$ \\
\hline Residuals & $\begin{array}{l}R B G \\
A G E \\
F E Y \\
G N F \\
S N F \\
W E \\
R E \\
C E\end{array}$ & $\begin{array}{r}8 \\
55\end{array}$ & $\begin{array}{l}2.064 \\
7.686\end{array}$ & $\begin{array}{l}0.002 \\
0.037 \\
0.038 \\
0.092 \\
0.194 \\
0.194 \\
0.211 \\
0.212\end{array}$ & $\begin{array}{l}0.002 \\
0.036 \\
0.001 \\
0.054 \\
0.101 \\
0.000 \\
0.017 \\
0.001\end{array}$ & $\begin{array}{r}0.007 \\
0.025 \\
-0.007 \\
0.163 \\
-0.088 \\
0.004 \\
0.121 \\
0.016 \\
-0.645\end{array}$ & $\begin{array}{r}0.043 \\
0.331 \\
-0.044 \\
0.242 \\
-0.312 \\
0.040 \\
0.134 \\
0.028\end{array}$ \\
\hline
\end{tabular}

Partial correlation $S N F-W E: r_{65.1234}=-0.063$. 